\title{
Referendums, Minorities and Individual Freedoms
}

By Marthe FATIN-ROUGE STEFANINI, Search Director CNRS, Aix-Marseille Univ, Université de Toulon, Univ. Pau \& Pays Adour, CNRS, DICE, ILF, Aix-en-Provence, France

\section{Introduction}

Referendums are often portrayed as instruments that are dangerous to rights and freedoms, in particular in the cases of minorities (Bell, 1978; Gunn, 1981; Gamble, 1997; Haider-Markel et al., 2007). This danger would come from a natural tendency of the majority to be tyrannical and discriminatory towards minorities. This fear was in fact an argument put forward by the Founding Fathers of the United States to outlaw referendums at the federal level (Magleby, 1995, 19-20), and that country is the source of the greatest number of studies on the impact of referendums on minorities. Those studies show that, statistically, the risks of infringement of the rights of minorities are greater in states where direct democracy procedures are employed (Lewis, 2011). Yet, the supposed hostility of referendum procedures to rights and freedoms has not always been taken for granted. For example, from the time of Jean-Jacques Rousseau's Social Contract to still recently in France, the sovereign people was perceived as best able to protect rights and freedoms, including by means of referendums (Fatin-Rouge Stefanini, 2003, 74). However, and more generally, the risk that referendums could kill freedom is a recurring criticism, and this criticism has grown louder with the crisis of representative democracy and rise of populism. In contrast, decisions adopted by representatives are reputed to be better able to protect minority rights because they are taken after deliberations in which various elements of the debate can be weighed one against the other (Eule 1990, 1525). Decisions made by representatives are thus the results of discussions and compromises that take into account the different interests at stake, and these include the protection of rights and freedoms, including those of minorities (Moeckli, 2011, 777). In contrast, referendums allegedly do not favour such balancing because they do not leave room for debate (see, for example, Lewis, 2011, 366). This is not always accurate since, among the broad range of referendum formats, some take place after debates in assemblies, which may make recommendations (for example, the messages from federal authorities in Switzerland concerning popular initiatives), formulate the question (for example, in the case of the Portuguese referendum on article 115 of the constitution), or decide on the content of a text (for example, the French referendum on article 89 of the constitution). However, it is true that no debate can really be held with citizens, or among citizens. They will just have the choice of adopting or rejecting a text, of answering "yes" or 
"no" to a question, of choosing among several possible responses, but they will not be able to negotiate the content of the proposals. The supposed opposition between referendums and freedoms is, however, revealing of evolution of the very notion of democracy. This debate contrasts the traditional conception of democracy, that is, "government of the people, by the people, for the people", with the modern conception of democracy, which is sometimes called "constitutional democracy". This conception integrates the rule of law and the respect for fundamental rights and freedoms proclaimed in constitutional and international texts. The classical conception leads to enshrining political choices directly determined by the majority of citizens; the modern conception is intended to submit expression of the majority will, even when expressed through a referendum, to compliance with the law. The theory of the sovereignty of the people amplifies the differences between these approaches because the sovereign people, original holder of power, is by nature unlimited and is even less able to impose limits on itself when it expresses itself directly through a referendum. Moeckli points out: "Simply stated, this debate opposes, on the one hand, who depict the people as the absolute sovereign on whose will, finding its expression on direct democratic processes, no limits can be imposed with, on the other hand, those who argue that in a state based on the rule of law, even the people must comply with certain fundamental rules, including respect for human rights" (2011, 775). Present-day respect for democratic values would therefore suppose that it is not possible to infringe on fundamental rights and freedoms, including by referendum. This theme is especially relevant in a period of return to grace of referendum procedures, in particular in the name of the need to allow the people to express itself directly on the issues that are the most important for the social, societal, political and economic future of states. Citizens themselves want to intervene more frequently in public debates and political decision-making; such participation is seen as a means of overcoming the real or supposed failure of their representatives to respond to their concerns in an appropriate manner. The increase of popular initiatives throughout the world in recent years can be analyzed as a consequence of this claim. However, this development is not without danger to rights and freedoms, since such initiatives can be powerful tools for challenging representatives' political choices, no matter what they are. While the risk that referendums could undermine freedom is real, especially for unpopular minorities, safeguards have nonetheless been established by some states to try to reconcile citizens' aims with the values to which modern democracies aspire.

\section{1) Earlier research and key literature on the problem}


A great many studies have been done on the dangers of referendums to minorities in the United States and, more recently and to a more limited extent, in Switzerland. Beyond these cases, recent research provides a spectrum of analysis that encompasses a few European cases, such as those of Hungary, Ireland and Lichtenstein (Marxer, 2012) as well as, more broadly member states of the Council of Europe, Latin America, Australia and New Zealand (Bochsler and Hug, 2009). Yet, given the few referendums outside of the United States and Switzerland, studies have often been very specific (focussing on one referendum in particular), or very general and theoretical. Indeed, aside from in those two states, referendums are so infrequent that a scientifically relevant comparative study on fundamental rights is difficult to conduct, ${ }^{1}$ especially since the national context of each referendum and the political context at the time when it was held must be taken into consideration.

There are various classifications proposed by doctrine on referendums, but for this study we have chosen a distinction based on the conditions for triggering referendum procedures suggested by Francis Hamon $(2012,17)$. Hamon breaks the various types of referendums into two groups: "top-down" referendums instituted by representatives (the executive, legislature, parliamentary minorities, deliberative bodies of territorial communities...) and "grass roots" referendums triggered by citizens themselves through popular initiatives. This classification has the advantage of encompassing under the term "referendum" a complete series of procedures: compulsory or optional referendums, propositional referendums initiated at the discretion of institutional bodies or by citizens, abrogating referendums (concerning old laws) and veto referendums (on new laws) instituted by citizen or parliamentary minorities. Popular initiatives can therefore be considered as ways of triggering referendums when they are "direct", in other words, when they necessarily lead to the holding of a vote if the conditions of admissibility are met. When an initiative results only in the proposal being studied by parliament, it is described as indirect ${ }^{2}$ (Eule, 1990, 1511) and we will not study it here. The states in which the number of referendums is the greatest are those where there are popular initiatives and, more generally, those where citizens can initiate referendums directly, whether the process is propositional, abrogating or designed to challenge a law that has just been adopted (veto referendum). The United States and Switzerland are the countries where the largest number of referendums are organized because citizens have the power to trigger referendums through popular initiatives at the level of the federal states in the USA, and at the level of communes, cantons and the federal government in Switzerland. 
Such "grass roots" referendums are suspected of generating greater risks to freedom than "topdown" referendums. However, several remarks have to be made before presenting the content. To begin with, the studies that have been done focus mainly on the discriminatory nature of some referendums, more than on how referendums in general place freedoms at risk. Yet, this distinction is important and merits that we ask questions about each of these terms. The rights and freedoms that will be taken into consideration are those qualified as "fundamental". According to Louis Favoreu's definition, the adjective "fundamental" applies to "the set of rights and freedoms ascribed to physical persons as moral persons (under both private and public law) in virtue of the constitution, but also in virtue of international texts, and protected from both executive and legislative power by constitutional and international judges" (1990, 581 [our translation]). The fundamental rights and freedoms taken into consideration are thus those that are provided for in state constitutions and the international agreements with which states have made a commitment to comply.

Infringement on a freedom can be to different degrees, from the smallest limitation to suppression. Simple adjustment of a freedom in its implementation cannot be considered as killing freedom so long as there is no decline in exercise of the freedom or limitation that is disproportionate to the objective. In some cases, the decline can affect a minority, but it can also affect all citizens, notably when there are grounds of general interest or public order that can be decided by referendum (e.g., a prohibition against smoking in public spaces).

Moreover, it is important to point out that the scope of fundamental rights and freedoms is relative since it depends on states' constitutional and conventional choices. Such relativism in terms of the recognition and protection of so-called fundamental rights and freedoms is especially an issue when it comes to sensitive topics that are considered societal choices, such as abortion, the death penalty, medically assisted suicide, marriage and adoption by couples of the same sex, etc. On these issues where the boundary between the status quo, the permissible restriction and the infringement on the fundamental right is tenuous, referendums are numerous.

Discrimination is an infringement of the right to equality in that it supposes that two situations that could be treated equally, are not. There are many forms of discrimination. The discrimination dealt with in international ${ }^{3}$ and constitutional ${ }^{4}$ texts is negative and generally prohibited by those texts. Some policies designed to correct inequalities have, in contrast, been described as positive discrimination in that they establish preferential treatment in order to foster de facto equality (affirmative action policies). Here, the forms of discrimination to which 
I will be referring are mainly negative forms suffered by minorities. However, positive discrimination is also interesting for this study because some minorities that used to be covered by positive discrimination policies, such as the Black minorities in the United States, women and homosexuals, have seen those policies challenged and submitted to popular vote in some member states of the USA. ${ }^{5}$

Finally clarifications must concern the notion of minority. There is no unanimity on the definition of that notion because, depending on the text and study, a group may be a minority in numerical, social or political terms. Thus, ethnic, religious and sexual minorities are numerical, whereas women were long a social and political minority, even though numerically they were sometimes in the majority. For this study, we will use Marxer's broad definition, which encompasses "not only ethnic, national, linguistic and religious minorities, but also social and political marginal groups and people with specific identifying characteristics - such as nondominant sexual orientation or disabilities" $(2012,8)$. People who have a criminal conviction can also be considered as a marginal social group, and thus as a minority.

Various studies take certain minorities into account - for example, ethnic and racial minorities (Bell, 1978; Hajnal, Gerber, Lounch, 2002), religious minorities (Christmann and Danaci, 2012), sexual minorities (Donavan and Bowler, 1998; Haider-Markel and al., 2007; Lewis, 2011), foreigners (Hainmueller and Hangartner, 2015) - as well as, more broadly, a number of groups that are social or political minorities (for example: Gamble, 1997, Lazos Vargas, 1999, Buchsler and Hug, 2009; Vatter and Danaci, 2010).

Most of the studies prior to the 2000s focussed on the United States and many of them denounced the discriminatory, conservative nature of decisions adopted by referendum, especially those that resulted from citizens' initiatives at the state level. The end of the nineteenth century and the twentieth century were marked by a number of racist or xenophobic popular initiatives, including those designed to exclude Black settlers (Johnson, 1995, 632), impose a certain level of education to exercise the right to vote (Oklahoma, 1910, the "GrandFather Clause") or prevent people of Japanese origin from becoming landowners (California, 1920, the Alien Land Law). Beginning in the 1960s, desegregation policies were targeted by referendums opposing fair distribution of housing between Blacks and Whites (anti-fair housing initiatives) and more equitable distribution of Black and White people in schools (antibusing initiatives). Those ballots were almost always unfavourable to minorities until they were challenged, either by a federal law (the Fair Housing Act of 1968), or the courts (Lazos-Vargas, 1999, 426). Then, beginning in the 1980s, referendums were held that were unfavourable to 
homosexuals, foreigners ("English only" initiatives and initiatives opposing bilingual education), immigrants in irregular situations (especially in southern states), people suffering from AIDS, and positive discrimination policies. There were also many proposals designed to make abortion laws stricter, in particular to require parents' consent in the case of minors. Lastly, in recent years, there has been a series of referendums against same-sex marriage.

With regard to all of these votes, and their often positive outcomes, which were therefore unfavourable to minorities, the United States seems to be the country in which there is the greatest discrimination and restriction of freedom by means of referendums. Swiss citizens, although notoriously conservative,${ }^{6}$ seem more reasonable, at least at the federal level, since, until 2004, they rejected virtually all of the referendums that could have infringed on rights and freedoms, including on those of minorities. Prior to 2004, only the initiative adopted on August 20, 1893, prohibiting "the slaughtering of livestock without having stunned it first" [our translation] was openly discriminatory against Jews and their religious traditions (Moeckli, 2011, 779). Jews were the unpopular minority at the time. In contrast, other later initiatives targeting foreigners in particular either did not receive enough signatures, and so were declared void (1995), or they were rejected. Studies carried out at the cantonal and local levels were, moreover, less alarming than in the United States (Frey and Goette, 1998). Switzerland attracted international attention only after the 2000s, following a series of popular initiatives that went against fundamental rights protected by certain international treaties and conventions. Four referendums in particular were subject to criticism owing to their positive outcomes and especially because of problems of compatibility with international law. They were referendums organized on the basis of a popular initiative proposing an amendment to the constitution since, at the federal level, popular initiatives are permitted only to amend the constitution partly or completely. ${ }^{7}$ The first initiative was adopted on February 8, 2004, and was entitled "Internement à vie pour les délinquants sexuels ou violents jugés très dangereux et non amendables" ["Life-long custody for non-curable, extremely dangerous sexual and violent criminals"]. The federal authorities had recommended that citizens reject that proposal, in particular because only a broad interpretation of its provisions, which did not correspond to the intentions of its authors, ${ }^{8}$ could make it compatible with the European Convention on Human Rights (ECHR). Nonetheless, $56.2 \%$ of the votes were in favour of adopting it, and it was introduced as article 123 of the federal constitution.

The second popular initiative received very strong international reactions because it was intended to prohibit the construction of minarets. Despite the federal authorities' 
recommendation that it be rejected, ${ }^{9}$ this proposal was adopted on November 29, 2009 with a majority of $57.5 \%$. It entered into effect immediately after having been introduced in article 72 , paragraph 3 of the constitution. In addition to the fact that this prohibition entered into contradiction with a number of provisions of the Swiss constitution that have the same legal weight as it, this prohibition is directly incompatible with article 9 of the ECHR, which guarantees freedom of religion, and article 14 of the ECHR, which prohibits any form of discrimination. This prohibition also contradicts articles 2, 18 and 27 of the UN Covenant on Civil and Political Rights.

The title of the third popular initiative that was approved was "Pour le renvoi des criminels étrangers" ["For the expulsion of foreign criminals"], and provided for the automatic deportation of foreigners who had committed certain offences or had received social benefits or assistance illegally. The proposal was adopted on November 28, 2010, with $52.9 \%$ of the votes. Like the preceding ones, the proposal was also incompatible with international law, in particular with the ECHR, the UN Covenant on Civil and Political Rights, the Convention on the Rights of the Child and the bilateral agreement between Switzerland and the European Union on free movement of persons. The federal authorities recommended rejecting the proposal and submitted a counter-proposal designed to respect the intentions of the authors of the initiative while ensuring compatibility with constitutional provisions and international law. ${ }^{10}$ The counter-proposal was rejected by the people.

Lastly, on February 9, 2014, the Swiss people adopted the initiative entitled "contre l'immigration de masse" ["against mass immigration"], which was designed to allow Switzerland to set annual quotas on the number of foreigners admitted. It challenged the bilateral agreement on free movement of persons between Switzerland and the European Union, and the federal authorities recommended it be rejected. ${ }^{11}$ It was adopted with $50.3 \%$ of voters in favour.

These differences in situation between the United States and Switzerland are also reflected in the results of studies conducted in the two countries. While some American authors showed that, in $78 \%$ of cases, referendum outcomes were unfavourable to minorities in the United States, (Gamble, 1997, 245; Lazos Vargas, 1999, 425), Swiss authors have shown, in contrast, that referendums, whether at the federal, cantonal or local level, have been, on the whole, favourable to rights and freedoms, with an overall rate of infringement of $30 \%$ (Frey and Goette, 1998, 1343). In both cases, the numbers advanced have been contested by other studies, which consider that the discriminatory impact on minorities is more limited or must be put into 
perspective since not all minorities are affected in the same way (regarding the United States: Donavan and Bowler, 1998; Hajnal, Louch, 2001; regarding Switzerland: Vatter and Danaci, 2011; Christmann and Danaci, 2012). The methods of analysis are not the same from one article to the next (in particular regarding the situations and minorities studied, and the scope of the study), and, consequently, among the studies done in the United States in particular, few come to similar conclusions (Matsusaka, 2005, 168). Nevertheless most of the studies conclude that the direct procedures of democracy are not favorable to minorities (Haider-Markel, Querze, Lindaman, 2007; Lewis, 2011; Donavan, 2013), or even to freedoms in general (Bochsler and Hug, 2009).

\section{III - The realities of referendums' danger to minorities and freedoms}

There are many examples of discriminatory or freedom-killing referendum propositions. However, the picture is not completely dark. Shades and tones have to be pointed out because each referendum is unique, occurs in a very specific context, and is subject to campaigns that can have considerable influence on the way people vote. Indeed, while referendums have strong potential for discrimination, especially against unpopular minorities (1), the negative effects of referendums have to be placed in perspective in some cases (2).

\section{1 - Proven danger for unpopular minorities}

The many examples of discriminatory referendums mentioned in doctrine do not target all minorities in the same way, but certain minorities whose unpopularity is climbing. Such unpopular minorities may be those demanding greater rights, such as in the case of the homosexual movement in the United States and other countries, or they may be minorities with no special political or social demands, but whom people are talking about because, in a given context, they give rise to fears - often unjustified or with no basis whatsoever - on the part of the majority. This is the case of Latin-American immigrants in the southern United States and foreigners - in particular those of the Muslim religion - in Switzerland, who are perceived as dangerous to the economy, culture and very identity of the host state.

Thus, a number of authors have proposed a distinction between "in-group minorities", which are not particularly affected by direct democracy procedures because they are considered as well integrated into the community, and "out-group minorities", which are perceived as little or not integrated, and therefore foreign to the community considered to be the majority (Vatter 
and Danaci, 2010, 205; Christmann and Danaci, 2012, 134). The less the minority group is considered as integrated, the more it will be likely to suffer discriminatory proposals in referendums. A number of elements can be added. To begin with, the acceptance of a minority varies from one state to the next. For example, Vatter and Danaci's study covering the federal and cantonal levels in Switzerland between 1960 and 2007 shows that direct democracy procedures did not affect the situation of homosexual people $(2010,157)$, while in the United States, beginning in the 1980s, they were targeted by a number of referendums. In contrast, in both states, foreigners were considered at different times as especially unpopular. Indeed, in Switzerland, this is the minority that has been most affected by direct democracy procedures (Vatter and Danaci, 2010, 212). However, within the "foreigner" category, all are not targeted in the same manner, as can be seen from local referendums on naturalization in Switzerland, which have caused problems owing to discrimination against applicants depending on their geographical origin (Hainmueller and Hangartner, 2015, 35).

Popular reaction to some minorities and some categories of people is also often related to a very specific context: a shocking current event (serial killing in the case of initiatives in favour of the death sentence or life imprisonment; massive immigration -sometimes escalated by war- in a state in loss of identity or suffering an economic crisis (Alvarez and Butterfield, 2000, 2); growth in power of a minority claiming rights and protection (homosexuals, Muslims in secular or Christian-majority states...)). Such initiatives may also be in reaction against political choices made by representatives or against court decisions perceived as activist in that they allegedly protect a minority against the majority will. Thus, Donavan says that "directdemocracy campaigns over questions of minority rights are not simply about a particular right and a particular minority group but may also reflect reaction to counter-majoritarian aspects of democracy that are facilitated by courts and representative government" $(2013,1743)$. He calls this reaction "populist backlash" $(2013,1740)$. Thus, anti-fair housing and anti-busing initiatives in the United States occurred in reaction to the desegregation policy; proposition 17 concerning the death penalty in California was approved in 1972 to counter the Supreme Court decision of the same year declaring capital punishment to be unconstitutional; ${ }^{12}$ in Ireland, one of the referendums proposed by the government in 1992 was on abortion and was directly intended to counter the Supreme Court decision of the same year that led abortion to be permitted in case of risk of suicide; ${ }^{13}$ in the United States, initiatives were filed against affirmative action policies following decisions by the Supreme Court in 1989, in City of Richmond v. J.A. Croson, ${ }^{14}$ and in 1995, in Adarand Constructors, Inc. v. Peña ${ }^{15}$ (LazosVargas, 1999, 455); proposals designed to prohibit same-sex marriage also followed a number 
of decisions favourable to homosexuals, in particular the Supreme Court of Hawaii decision in 1993, which considered that refusing to marry a homosexual couple was discrimination in violation of the state constitution, ${ }^{16}$ and the Supreme Court of Massachusetts in 2003 authorizing same-sex marriage ${ }^{17}$ (Donavan, 2013, 1747); in Slovenia, the 2004 referendum initiated by the conservative opposition on the question of the "Erased" directly targeted a Slovenian constitutional court decision in 2003 that challenged the legislation's strict conditions on regularization of such situations (Hassid, 2015); ${ }^{18}$ etc.

The unpopularity of a minority targeted by a referendum is also often amplified in the context of campaigns led by lobbies or political parties that stigmatize the minority by blaming it for society's various ills (Bell, 1978, 20) in an unsubtle and often deceitful manner. Indeed, some political parties are aware that they can take advantage of such stigmatization and, through wellorganized, generously funded campaigns, take advantage of direct democracy mechanisms to criticise the political choices of parties in power in a more general way. This is especially the case with respect to foreign minorities, or minorities considered to be foreign, which are directly targeted by political parties, often on the extreme right, wishing to intensify nationalist sentiments, as is the case in the United States, Switzerland and also Slovenia, with respect to the "Erased". As Sylvia Lazos-Vargas has pointed out regarding proposition 187 against immigrants in irregular situations in California: "Illegal immigrants, a highly unpopular group, are an easy target for politicians who perceive that they can gain an electoral advantage by positioning themselves as being 'against' such groups". ${ }^{19}$ Likewise, in Switzerland, the initiatives against foreigners and Muslims supported by the Swiss People's Party have considerably aided the rise of that political party (Moeckli, 2011, 780).

For unpopular minorities, direct democracy procedures seem to increase discrimination in two ways. On one hand, a number of studies show that representatives, not only because they discuss decisions to be taken among themselves within assemblies, but also because they have to justify their choices (Hainmueller, Hangartner, 2015, 34), are likely to make decisions that are more favourable to minorities. Representatives take into account a complex set of data, to justify a decision that will, in principle, be reasonable. In contrast, a referendum vote is considered more emotional than reasonable, especially since the various arguments and elements of the debate are often extremely simplified in referendum campaigns. Voters do not have to answer for the positions they take; the vote is "anonymous" (Christmann and Danaci, 2012, 136). Moreover, some authors have shown that the negative effects of referendums on minorities are not always immediately visible at the time of the vote (Lewis, 2011). The very 
existence of direct democracy mechanisms can have indirect effects, beyond the vote itself, on representatives. For example, Lewis (2011, 367, 376), and Christmann and Danaci, (2012, 147, 153) show, regarding same-sex marriage in the United States and the policy applying to Muslims in Switzerland, that the parliaments of the states where there are direct democracy mechanisms are influenced by the very existence of those mechanisms and can, owing to this, be tempted to adopt stricter legislation targeting minorities out of fear of political reprisals (in the form of popular initiatives, recall or failure to be re-elected) by the majority of citizens. ${ }^{20}$ Minorities are thus in a lose-lose situation in that they are affected both by the decisions of the majority of citizens, but also by those of the majority of representatives. States that have direct democracy mechanisms that can be set into motion by citizens' initiatives are allegedly more conservative than states that do not have such mechanisms (Matsusaka, 2007, 20; Lewis, 2011, $367,376)$. Such conservatism apparently affects not only the rights of minorities, but also fundamental rights in general, as a study on 52 states tries to show concerning a number of rights and freedoms: women's social and economic rights, the rights of sexual minorities, abortion rights, freedom of expression, freedom of assembly and association (Boschler, Hug, $2009,22)$. The results of studies are however interpreted in accordance with the themes addressed; the issue of abortion, for example, apparently reveals a more open-minded attitude on the part of voters (Matsusaka, 2007; Buchsler and Hug, 2009). In contrast, the conservative reflex is obvious with respect to the theme of the death penalty in the United States. In November 2016, three states decided in referendums to maintain the death penalty or to challenge a law abolishing the death penalty (California, ${ }^{21}$ Oklahoma, ${ }^{22} \mathrm{Nebraska}^{23}$ ).

\section{2 - Discriminatory effects to be brought into perspective}

Discriminatory referendums are highly mediatized, and the many debates and criticisms to which they give rise tend to strengthen the feeling that referendums are a major danger to rights and freedoms. While there is this danger, it must be seen in relative terms in a number of respects.

To begin with, in Switzerland, for example, the successes of recent years have to be viewed in relation to the very large number of potentially discriminatory popular initiatives that failed, either at the signature-gathering or at the voting stage, as can be seen on the website of the Federal Chancellery. ${ }^{24}$ All of the popular initiatives targeting foreigners prior to 2010 failed, including the initiative designed to overturn the jurisprudence of the Federal Supreme Court, ${ }^{25}$ which means that naturalization can no longer be decided by referendum at the local level. ${ }^{26}$ 
In the United States, while a certain number of proposals targeting minorities have ended up being adopted, ${ }^{27}$ most of them have been challenged at the federated or federal level, and when a fundamental right is in question, the provisions adopted have strong chances of being declared unconstitutional by federal courts (see IV below).

It is also important to look more closely at the content of the referendum before drawing general conclusions. Manifestly discriminatory or provocative referendums that lead to a step back in minority rights or to a clear decline in freedom are generally - though not always - rejected (Lazos-Vargas, 1999, 431, 432 concerning certain initiatives against homosexuals and people suffering from AIDS in the United States). In especially tense situations, discriminatory and regressive arguments concerning protection for fundamental rights can, however, be the recipe for success (Mockli, 2011, 790). In contrast, referendums on proposals to maintain the status quo by opposing legislation or court decisions considered as favourable to minorities or on proposals against giving new rights to minorities have greater chances of being adopted (Christmann and Danaci, 2012, 155; Marxer, 2012, 165). According to those analyses, the rights of minorities are affected mainly when what is in question is their progress, in other words, the expansion of their rights; in contrast, it is rare to see true steps back in the rights of minorities, such as with proposition 187 in California or the prohibition against minarets in Switzerland. This reading of referendums can explain why, in the case of same-sex marriage, most American and European states $\left(\right.$ Croatia $^{28}$, Slovakia ${ }^{29}$, Slovenia $\left.{ }^{30}\right)$ that held referendums on that theme refused to give that right to the homosexual minority: members of that minority were asking for equality with respect to access to marriage, which was synonymous to them with progress in recognition of their rights. This attitude is also revealing of the conservatism of which direct democracy measures are generally accused. However, some authors have shown that when minority rights are encompassed in broader reforms, in particular in constitutional revisions, progress can be made in fundamental rights, including for unpopular minorities (Christmann and Danaci, 2012, 154). Expanding the proposed reform to integrate into it less popular measures makes it possible to avoid polarizing attention on one minority in particular, and thereby to dilute the negative resentment that the majority might express towards that minority if it were to be questioned specifically on that minority's rights.

While it is true that states such as Switzerland have been slower to accept reforms related to societal issues (women's right to vote, abortion, same-sex marriage...), referendum procedures can also be shown to be more liberal. Indeed, the great majority of studies focus attention on 
the danger that popular initiatives and referendums present for minorities, and it is rare to find one that bucks the apparent general trend toward defeatism and highlights the fact that direct democracy mechanisms can also be a means of acquiring new rights. For example, in 1994, Oregon adopted a popular initiative permitting medically assisted suicide, and, despite opponents' efforts, this measure has not been challenged since (Purvis, 2012, 271). Oregon was even the precursor in this area; it was followed a few years later, in 2008, by the State of Washington, which held a referendum on medical assistance for suicide, in which the outcome was positive, with $58 \%$ of the votes. As of 2016, eight USA states had approved by referendum the legalization of marijuana or cannabis use for recreational or medical purposes. Similarly, Ireland, going against the current in most American states, was the first state to accept homosexual marriage by referendum. ${ }^{31}$ A compulsory constitutional referendum also allowed the Irish to confirm, in 2001, the law that had prohibited the death penalty since 1990 and to provide in the constitution that the death penalty cannot be reinstated under any circumstances, even in time of war. ${ }^{32}$

The danger to freedoms seems higher when direct democracy procedures are actively employed than when representative institutions have the power to make decisions without having their choices subject to being threatened by a referendum. However parliamentary process is no absolute guarantee of protection of freedoms and respect for the rights of minorities. This justifies establishing anti-majority filters in order to limit the omnipotence of the parliamentary majority; in particular, acts adopted by parliaments are subject to judicial review, which is a way of preserving, notably, fundamental values enshrined in the constitution. Similarly, a certain number of safeguards have been developed in recent years with respect to direct democracy and, even though they are sometimes challenged on the basis that they deconsecrate the outcomes of referendums, they reveal awareness of referendums' dangers to rights and freedoms.

\section{IV - Guarantees to limit referendums' threat to freedoms and minority rights}

Many states became aware, more or less long ago, of the dangers that direct democracy procedures can create for the rights of minorities and fundamental freedoms in general. There are ways to limit these risks. To begin with, the choice may be to have an exclusively representative regime that provides for no form of referendum intervention at all at the national, federal or local level. This radical solution is, however, difficult to defend in an era when many states are dealing with crises in representation, and when citizens are seeking to participate 
more fully in public affairs and to intervene directly in political decision making, even though those decisions may be complex. Therefore, even in long-standing democracies, exclusively representative by tradition, referendum mechanisms have been introduced, either by law on a case-by-case basis (Holland, the United Kingdom) or in the constitution at the local level $\left(\right.$ Belgium $\left.^{33}\right)$. Some states have chosen to prohibit referendums on the national or federal level (Germany, ${ }^{34}$ the United States) while authorizing them at the local or federated level. Indeed, in Germany and the United States, direct democracy procedures have developed largely at the level of the Länder and the states. ${ }^{35}$ This principle of organization has a major advantage: at the federated level, citizens can make proposals or express their opposition to political choices, norms or court decisions adopted at the federal level, but within the limits of respect for the federal constitution and, notably, the rights and freedoms that it guarantees. Thus, the principle of a hierarchy of norms and that of respect for the federal constitution make it that, through judicial review, constitutional courts are, in principle, able to set aside discriminatory referendum choices adopted at the level of federated states.

Another way to limit the risk of discrimination or elimination of freedoms is to leave the national or federal referendum initiation procedure in the sole control of those in power. Most states do not allow a minority of citizens or a political minority (determined by a minimum number of parliamentarians) to trigger referendum procedures (for example, Austria, ${ }^{36}$ Spain, ${ }^{37}$ Greece, ${ }^{38}$ Ireland ${ }^{39}$ ), or they make the conditions to be met so difficult that it is practically impossible for a referendum to be held (France, ${ }^{40} \mathrm{Russia}^{41}$ ). Thus, referendums remain a form of recourse that is exceptional and controllable by government or parliament as to avoid any abuses. However, this does not prevent those in power from proposing discriminatory referendums themselves, as can be seen, for example, from the 1992 referendum on abortion in Ireland, on a question designed to challenge the Supreme Court decision, ${ }^{42}$ and the referendum in Hungary on October 2, 2016, targeting the European Union's policy on migration quotas, and thus, indirectly, migrants. ${ }^{43}$

Some states have also decided to shelter fundamental rights and freedoms from popular votes by adopting provisions that limit the areas to which referendums can apply. This limit can be general, providing that some referendums initiated by citizens cannot concern constitutional questions, and thus cannot amend the constitution. For example, in Italy, article 75, paragraph 1, which provides for referendums on repealing legislation, states: “A popular referendum shall be held to abrogate, totally or partially, a law or an act having the force of law..." [our 
emphasis]. This excludes provisions in the constitution, and therefore a provision on fundamental rights and freedoms, from being the targets of abrogating referendums. (This was the case, for example, of a radical proposal to repeal the law on abortion in $1981 .{ }^{44}$ ) The situation is the same in Portugal, where article 115, paragraph 4 expressly removes constitutional amendments from the field of referendums. That limit can also be more specific and directly target the category of fundamental rights and freedoms. This is the case of referendums in Slovakia (article 93, paragraph 3 of the constitution) and with respect to popular initiatives in Mississippi (article XV, section 273, part 5). ${ }^{45}$ The limitation can also target, as in Massachusetts, only certain freedoms (article XLVIII, part 2 of the constitution ${ }^{46}$ ). However, these limits can be respected only at the cost of efficient control of compliance with provisions on referendums.

The efficiency of control over referendums will depend on the authority that performs it, the jurisdiction and margin of manoeuvre that authority has, the impacts of its decisions and, more generally, the system of which it is a part. It is, however, important that the authority responsible for making the decision be independent, which entails a priori setting aside control by political authorities. Thus, in Europe, after World War II and the fall of the Berlin Wall, a number of new democracies that had been victims of authoritarian regimes introduced or reintroduced into their constitutions direct democracy procedures that could be initiated by citizens. These procedures were often enshrined at the price of strict control over them out of fear of antidemocratic hijacking of referendum tools and destabilization of institutions that were sometimes still fragile. The referendums were therefore accompanied by procedures to ensure prior control over referendum proposals, and that control was generally placed in the hands of constitutional courts (Albania, ${ }^{47}$ Croatia, ${ }^{48}$ Italy, ${ }^{49}$ Portugal, ${ }^{50}$ Romania, ${ }^{51}$ Russia, ${ }^{52}$ and Slovakia: ${ }^{53}$ Fatin-Rouge Stefanini, 2017).

Such control prior to the holding of a referendum flows from a concern to "rationalize" the direct expression of the general will (Taillon, 2012, 479) so as to preserve the constitution and the various interests it encompasses.

Control performed before the vote so as to prevent referendums from being held that could infringe on fundamental rights and freedoms has a major advantage, which is that this avoids tensions created by the campaigns themselves. However, such preventive control is not always possible or desirable. In the United States, for example, the courts rarely agree to verify the legality and constitutionality of the merits (the substantive grounds) of referendum proposals, 
especially when they are popular initiatives, before the vote is held. There are a number of reasons for this. To begin with, when a popular initiative is provided for under the constitution, it is considered to be a citizens' right that is constitutionally protected at the state level (Radcliffe, 1994, 425). Preventive control is thus perceived by some courts as infringement on citizens' rights. ${ }^{54}$ Moreover, technical reasons can be advanced by the courts in the American justice system to justify the absence of control over the content of proposals submitted to referendums: the prohibition against advisory opinions, the need for cases to be in a state amenable to judgment and thus on concrete issues, and the fact that court intervention must be on a strictly necessary basis ... (Gordon and Magleby, 1989, 304). Thus, those affected by a referendum decision must wait until the disputed provision comes into effect before initiating legal proceedings and, in most cases, such proceedings occur after the vote, if the outcome is positive. Some so-called activist courts are more open to exercising control before the vote, or interpret more broadly their formal control over the manner in which the question, proposal or title of the proposal is written. For example, the Arkansas Supreme Court struck a number of referendum proposals from the ballot a few days before the vote was to be held for reasons related to the vagueness of the proposals as formulated in the titles or in the texts. ${ }^{55}$

However, a posteriori controls, although respecting the freedom of expression of voters and a form of sovereignty of the people in the Federated States, raise some political difficulties in the United States. Indeed, at the federal level, the judges in the various state courts are often elected. And it happened on several occasions that their position on certain cases, which had led them to censure the referendum decision, caused them to be recalled or not being reelected (Eule, 1990,1582; Donavan, 2013, 1741). As a result, some judges express their discomfort at the decisions adopted by popular vote and tend to show some form of deference towards them. However, in the United States, many proposals - even constitutional amendments - adopted or amended at the state level are being challenged in court for non-compliance with the federal Constitution. The Federal Courts and ultimately the Supreme Court of the United States have thus invalidated several provisions considered to be discriminatory or contrary to rights and freedoms. Thus, for example, the Romer v. Evans' decision, according to which Amendment No. 2 to the Constitution of Colorado was discriminatory for gays and lesbians, or the Obergefell v. Hodges' decision, which invalidated - on the basis of the XIV Amendment - all state provisions, whether adopted or not by referendum, prohibiting marriage between persons of the same sex. It should be noted, however, that the constitutional recognition of a right even at the federal level does not prevent new initiatives from being filed in order to circumvent 
either the constitutional provision or the court decision recognizing that right, as has been the case for example with abortion issues following the Roe v. Wade's decision by the Supreme Court in 1973 (Carter, 2011, 305). In Europe, even in the case of constitutional provisions that discriminate or threaten individual freedoms adopted by referendum, a final appeal can be lodged with the European Court of Human Rights, which may declare the decision incompatible with the Convention. This has been the case, for example, with the provisions of the Irish Constitution on abortion, introduced by referendum in 1983, which prohibited associations from publishing information on the possibility for Irish women to have abortion abroad (CEDH, 29 October 1992, Open Door and Dublin Well Woman v. Irlande).

Judicial intervention, whether before or after voting, has the further virtue of shifting the debate on the legal level and thus offering answers based on the right to political questions with a high emotional content. Such answers usually help alleviate this tension since fundamental democratic values are recalled.

In Switzerland, the problem raised by referendums at the federal level is still different. Indeed, popular initiatives that have aroused controversy have a constitutional status since it is allowed at federal level to propose a constitutional revision by means of a popular initiative. However, because of their place in the hierarchy of norms and the great respect traditionally accorded to popular rights and the decisions adopted directly by citizens in this country, popular initiatives enjoy full immunity. An a priori control of the admissibility of popular initiatives is actually provided for in the Constitution ${ }^{56}$, but not only is it exercised by a political authority - the Federal Parliament - but it is also rather succinct. Indeed, until 1994, the control of admissibility, apart from the requirements for the collection of signatures, was limited to respect for the unity of form, which concerns the way in which the initiative is drafted, and the unity of matter, which means that the popular initiative must not deal with separate subjects, without relations between them, on which citizens might want to express different opinions. Since 1955, the Federal Parliament also controls the executability of the popular initiative ${ }^{57}$. In the mid-1990s, the Federal Assembly was faced with an initiative entitled "For a reasonable policy of asylum" which violated several international conventions (including the Geneva Convention of 8 July 1951, the European Convention on Human Rights, the United Nations Convention against Torture and the International Covenant on Civil and Political Rights), by prohibiting in particular the right to appeal for asylum seekers. This initiative was declared void in the name of respect for the rules of international law ${ }^{58}$ - jus cogens - and this new limit was enshrined in 
the Constitution during the 1999 total revision. However, this limit has not prevented the holding of other popular votes leading to the adoption of discriminatory provisions since 2004, since even if these provisions are contrary to international law, the rules of jus cogens are not at issue. These initiatives raise problems of compatibility between national constitutional law and international law, without the question of the primacy of one or the other having been finally settled. Consultations were held on the possibility of introducing new limits taking into account, for example, the protection of the "essence of fundamental rights"; however, faced with the difficulty of agreeing on the content of these limits, no reform has yet been undertaken (Moeckli, 2011, 786).

However, the Swiss authorities, hampered by the stigmatization of these initiatives at diplomatic and international levels, have tried, where possible, to find compromise solutions in the implementation of these new provisions in order to ensure respect for the law international. With respect to the 2004 initiative on life internment for sexually or violent offenders found to be very dangerous and non-amendable, the federal Parliament, using its power to interpret adopted proposals in their implementation phase, has adopted in 2007 an implementing law enabling its conformity with international law (Article 64 (1) (a) of the Criminal Code) ${ }^{59}$.

Similarly, with respect to the 2010 initiative on "Removal of Foreign Criminals", the federal Parliament relaxed the rigor of the rule adopted by referendum in its enforcement measures by providing, inter alia, a degree of discretion left to the judge to decide expulsion, in spite of the fact that this room for manoeuver (which had been proposed in a counter-project voted together with the initiative) had been expressly rejected by the voters. In response to these implementing measures, however, new popular initiatives have been introduced ${ }^{60}$, which shows that the solutions of compatibility found by the Parliament for certain initiatives are fragile, all the more since international law and the law of the ECHR, particularly in Europe, is increasingly contested by States, with the result that the guarantee of fundamental rights and, beyond, the respect for democratic values, appears increasingly challenged.

\section{V-Conclusion :}

It is difficult to draw general conclusions about the effects of referendums on fundamental rights and freedoms. The procedure for calling the referendum, the questions that can be put to 
the vote, the rank of the rules adopted in the hierarchy of norms, the context of the referendum, the subject matter, how the question is formulated, how the campaign is organized and funded, are all factors that must be taken into account in order to understand why certain referendums may infringe rights and freedoms, in particular minorities, in certain States, and why this is a limited or non-existent risk in others. The case of Switzerland is topical and has attracted much attention in so far as, faithful to a traditional conception of democracy and confident in a system that has worked relatively well for a century - thanks in particular to the sometimes very motivated messages of the Federal assemblies and to the technique of the counter-project rights and freedoms, including those of minorities, seemed preserved. The wisdom of the Swiss population seemed to be able to protect against the risk of violating the freedoms. However, in a troubled period, the balances on which the Swiss democratic system rests are found to be fragile, which makes it necessary to provide appropriate mechanisms to ensure respect for the fundamental rights of minorities. Such mechanisms exist in many countries which have become aware of the importance of allowing citizens to participate more actively in political life but also of the need to frame the popular will in the name of respect for the different components of democracy. These counter-majoritarian mechanisms make it possible to deal with the brutality of certain proposals submitted to popular vote, while respecting democratic values, either by preventing referendums on issues that are particularly sensitive to rights and freedoms or by allowing the debate to continue in front of the courts, and may even lead to a revision of the Constitution or to the renunciation of a treaty (which has not yet occurred), but after a genuine democratic reflection on the choices to be made.

\section{References}

Alvarez, R. Mickael, Butterfield Tara L., (2000), The Resurgence of Nativism in California? The Case of Proposition 187 and Illegal Immigration, Social Science Quaterly, 81 (1), 167.

Bell Derrick A., (1978), The Referendum : Democracy's Barrier to Racial Equality, Washington Law Review, 54 (1), 20.

Bochsler Daniel, Hug Simon, How Minorities Fare under Referendums. A Cross-national Study, Paper prepared for presentation at the ECPR General Conference Postdam 10-12 september 2009.

Carter Molly E. (2011), Regulating Abortion Through Direct Democracy : The Liberty of All versus the Moral Code of the Majority, Boston University Law Review, 91, 305.

Christmann, Anna and Danaci, Deniz (2012), Direct Democracy and Minority Rights : Direct and Indirect Effects on Religious Minorities in Switzerland. Politics and Religion, 5(1), 133. 
Danaci, Deniz (2012), The Minaret Ban in Switzerland: An Exception to the Rule? in Marxer Wilfried (ed.), (2012), Direct Democracy and Minorities, 155.

Danilenko D., (2005), Le référendum en Russie : une expérimentation démocratique, Revue française de droit constitutionnel, 62, 443.

Donavan Todd, (2013), Direct Democracy and Campaigns Against Minorities, Minnesota Law Review, 97, 1730.

Donavan Todd, Bowler Shaun, (1998), Direct Democracy and Minority Rights : An Extension, American Journal of Political Science 52, 1020.

Eule Julian N., (1990), Judicial Review of Direct Democracy, 99 Yale Law Journal, 1503.

Frey Bruno S. and Goette Lorenz (1998), Does the Popular Vote Destroy Civil Rights, American Journal of Political Science, 42, 1343.

Fatin-Rouge Stefanini Marthe, (2003), Le référendum et la protection des droits fondamentaux, Revue française de droit constitutionnel, 53, 73.

Fatin-Rouge Stefanini Marthe, (2017), Le contrôle de la recevabilité des référendums en droit comparé ou la recherche d'un équilibre entre différentes exigences démocratiques, in Taillon P. et Binette A., La démocratie référendaire dans les États plurinationaux, Québec, Presses de l'Université Laval [forthcoming]

Favoreu Louis (1990), «L'élargissement de la saisine du Conseil constitutionnel aux juridictions administratives et judiciaires », Revue française de droit constitutionnel, 581.

Gamble Barbara (1997), Putting Civil Rights to a Popular Vote, American Journal of Political Science, 41, 245.

Gordon James and Magleby David (1989), Pre-Election Judicial Review of Initiatives and Referendums, Notre-Dame Law Review, 64, 298.

Gunn Priscilla F. (1981), Initiatives and Referendums : Direct Democracy and Minority Interests, Urban Law Annual Review, 22, 135.

Haider-Markel Donald P., Querze Alana, Lindaman Kara, (2007), Lose, Win, or Draw ? A Reexamination of Direct Democracy and Minority Rights, Political Research Quaterly, 60 (2), 304.

Hainmueller Jens, Hangartner Dominik, (2015), Does Direct Democracy Hurt Immigrant Minorities? Evidence from Naturalization Decisions in Switzerland, American Journal of Political Science, forthcoming.

Hajnal Zoltan, Louch Hugh, (2001), Are There Winners and Losers ? Race, Ethnicity and California's Initiative Process, Public Policy Califormia Institute Publication, 100 p. 
Hajnal Zoltan J., Gerber Elisabeth R., Louch Hugh, (2002), Minorities and Direct Legislation : Evidence from California Ballot Proposition Elections, The Journal of Politics, 64 (1), 154.

Hamon Francis, (2012), Le référendum. Etude comparative, 2e éd., LGDJ, 229 p.

Hassid Laurent, «Le concept de minorité en Slovénie : le cas des minorités ethniques », Mémoire(s), identité(s), marginalité(s) dans le monde occidental contemporain [En ligne], $13 \mid 2015$, mis en ligne le 30 juin 2015, consulté le 21 décembre 2016 (URL: http://mimmoc.revues.org/2087).

Johnson Kevin R., Symposium on Immigration Policy: an Essay on Immigration Politics, Popular Democracy, and California's Proposition 187: The Political Relevance and Legal Irrelevance of Race, Washington Law Review, 70, 629.

Lazos Vargas, Sylvia R., (1999), Judicial Review of Initiatives and Referendums in Which Majorities Votes on Minorities' Democratic Citizenship, Ohio State Law Journal, vol. 60, 315.

Lewis Daniel C., (2011), Direct Democracy and Minority Rights : Same Sexe Mariage Bans in the United States, Social Science Quaterly, 92 (2), 364.

Lewis Daniel C., (2013), Direct Democracy and Minority Rights : A Critical Assessment of Tyranny of the Majority in American States, Routledge, 129 p.

Magleby, David B., (1995), Governing by Initiative, Let the Voters Decide? An Assessement on Initiative and Referendum Process, Univ. of Colorado Law Review, vol. 66, 13.

Marxer, Wilfried (ed.), (2012), Direct Democracy and Minorities, Wiesbaden, Springer VS, $254 \mathrm{p}$.

Matsusaka John, (2005), The Eclipse of Legislatures : Direct Democracy on the 21st Century, 124, Public Choice, 157.

Matsusaka John, (2007), Direct democracy and Social Issues, Working paper, USC Marshall School of Business, available on line.

Moeckli Daniel, (2011), Of Minarets and Foreign Criminals : Swiss Direct Democracy and Foreign Law, Human Rights Law Review, 774.

Purvis Taylor (2012), Debating Death : Religion, Politics, and the Oregon Death with Dignity Act, Yale Journal of Biology and Medicine, 85 (2), 271.

Radcliffe M. Sean (1994), Pre-Election Judicial Review of Initiative Petitions : an Unreasonable Limitation on Political Speech, Tulsa Law Journal, 30, 425.

Rohner Andreas (2011), Direct Democracy in the German Länder: History, Institutions and (Mal) Functions, C2D Working Paper series, 42 p. (Available on line).

Taillon Patrick, (2012), Le référendum expression directe de la souveraineté du peuple?, Dalloz, Paris, 586 p. 
Vatter Adrian, Danaci Deniz, (2010), Mehrheitstyrannei durch Volksentscheide? : zum Spannungsverhältnis zwischen direkter Demokratie und Minderheitenschutz, Politische Vierteljahresschrift, 51, 205.

\footnotetext{
${ }^{1}$ See, however, Boschler and Hug (2009) for a study of the influence of the existence of direct democracy mechanisms on Parliament decisions involving minority rights and civil rights.

${ }^{2}$ See, for example, the indirect popular initiative provided for in article 71 of the Italian Constitution.

${ }^{3}$ Article 6 of the International Covenant on Civil and Political Rights.

${ }^{4}$ See, for example, Article 3 of the German Basic Law, Article 11 of the Belgian Constitution or Article 14 of the Spanish Constitution. Most often, the constitutions mention prohibited "distinctions": for example, the French Constitution guarantees "equality before the law of all citizens without distinction of origin, race or religion" (Article 3).

5 See, in particular, regarding positive discrimination in favour of homosexuals, Amendment No. 2 in Colorado in 1992, Proposal 209 in California in 1996, and Initiative 200 in Washington State in 1998.

${ }^{6}$ E.g. about the right to vote. Women did not acquire this right at federal level until 1971 and in some cantons it was granted only in 1990 .

${ }^{7}$ Art. 138 and 139 of the Constitution, an amendment which will be submitted to the referendum (article 140 of the Constitution).

${ }^{8}$ Message from the Federal Council, Federal Law (FF) 2001 3265. For the Parliament: FF 20033979.

${ }^{9}$ FF 20086923 et FF 20093903.

${ }^{10}$ FF 20094571 et FF 20103853

${ }^{11}$ FF 2013279 et FF 20136575.

${ }^{12}$ Furman v. Georgia, 480 US 238, and, at the level of California : People v. Anderson, 493 P.2d 880, 6 Cal. 3d 628 (Cal. 1972).

${ }^{13}$ Attorney General v. X, [1992] IESC 1; [1992] 1 IR 1.

14488 U.S. 469 (1989).

15515 U.S. 200 (1995).

${ }^{16}$ Baehr v. Lewin, 852 P. 2d 44 (Haw.1993).

${ }^{17}$ Goodridge v. Dep't of Pub. Health, 798 N.E.2d 941 (Mass. 2003).

${ }^{18}$ The referendum was held on April 24, 2004. 31.54\% of the voters participated in the vote and rejected the law
} applying this decision to $94.59 \%$.

$191999,453$.

${ }^{20}$ The same observations can be made for other minorities. For migrants, see, for example, Lazos Vargas, 1999, $473,474$.

${ }^{21}$ California, Proposal 62, Repeal of the Death Penalty. The purpose of this proposal was to abolish the death penalty that was reintroduced by referendum in 1978, after the procedure was declared unconstitutional by the Supreme Court of California in 1972 (People v. Anderson).

22 Oklahoma Death Penalty Amendment, State Question 776.

${ }^{23}$ Nebraska, Referendum 426, Death Penalty Repeal. This veto-referendum is against the law LB 268, passed in May 2015, prohibiting the death penalty in Nebraska. It was adopted with $60.64 \%$ of the cast votes (source: ballotpedia).

${ }^{24} \mathrm{https}: / / \mathrm{www} . \mathrm{admin} . \mathrm{ch} / \mathrm{ch} / \mathrm{f} / \mathrm{pore} / \mathrm{vi} / \mathrm{vis} \_2 \_2 \_5 \_1 . \mathrm{html}$ ?lang=fr

${ }^{25}$ Decisions of the Swiss Federal Court of 9 July 2003: ATF 129 I 217 and ATF 129 I 232.

${ }^{26}$ Popular initiative "For democratic naturalisations" refused on 1 June 2008.

${ }^{27}$ See ballotpedia.org, which lists by subject, state and year all proposals submitted for voting (https://ballotpedia.org/List_of ballot_measures_by topic).

${ }^{28}$ Referendum of 1 December 2013 deciding to write in the Constitution that marriage can only be celebrated between a man and a woman.

${ }^{29}$ Although the Constitution only permits marriage between a man and a woman, a minority initiative consultation was held on 7 February 2015, asking three questions, one to go further in the prohibition of samesex marriage and another one to deny adoption by homosexual couples. Although the results of this consultation were largely positive, they were invalidated because of the quorum of participation not met.

${ }^{30}$ Referendum of 20 December 2015 rejecting the law authorizing marriage between persons of the same sex.

${ }^{31}$ Referendum of 22 May 2015.

32 This inscription was probably influenced by Ireland's desire to ratify the Additional Protocol 13 to the ECHR on the abrogation of the death penalty in all circumstances. 
${ }^{33}$ Articles 39 bis and 41 of the Constitution.
${ }^{34}$ Except in the exceptional case of Article 146 of the Constitution.
${ }^{35}$ For the United States, see especially the Ballotpedia site. For the German Länder, see, among others, Rohner

A. (2011).

${ }^{36}$ Article 43 of the Constitution provides that Parliament may submit a law to a referendum. Moreover, the total constitutional revision is subject to a mandatory referendum (Article 44).

${ }^{37}$ Article 92 of the Constitution.

${ }^{38}$ Article 44 of the Constitution.

${ }^{39}$ Article 47 of the Constitution.

${ }^{40}$ Article 11 para. 3 of the Constitution, providing for the referendum "of shared initiative", which can be

triggered by $1 / 5$ of the members of the Parliament supported by $1 / 10$ of the electorate.

${ }^{41}$ See Danilenko D., (2005), 443.

${ }^{42}$ In Ireland, recourse to a referendum is compulsory for the adoption of a revision of the Constitution (Article 46 of the Constitution).

${ }^{43}$ The positive results of this referendum were invalidated for lack of sufficient participation.

${ }^{44}$ Constitutional Court, Sentence No. 26/1981 of 10 February 1981.

${ }^{45}$ According to this provision : «(5) The initiative process shall not be used:

(a) For the proposal, modification or repeal of any portion of the Bill of Rights of this Constitution;

(b) To amend or repeal any law or any provision of the Constitution relating to the Mississippi Public Employees' Retirement System;

(c) To amend or repeal the constitutional guarantee that the right of any person to work shall not be denied or abridged on account of membership or non-membership in any labor union or organization; or

(d) To modify the initiative process for proposing amendments to this Constitution. (...)

${ }^{46}$ According to this provision : "No measure that relates to religion, religious practices or religious institutions; or to the appointment, qualification, tenure, removal, recall or compensation of judges; or to the reversal of a judicial decision; or to the powers, creation or abolition of courts; (...) shall be proposed by an initiative petition (...) No proposition inconsistent with any one of the following rights of the individual, as at present declared in the declaration of rights, shall be the subject of an initiative or referendum petition: The right to receive compensation for private property appropriated to public use; the right of access to and protection in courts of justice; the right of trial by jury; protection from unreasonable search, unreasonable bail and the law martial; freedom of the press; freedom of speech; freedom of elections; and the right of peaceable assembly".

${ }^{47}$ Articles 150 to 152 of the Constitution.

${ }^{48}$ Articles 87 and 95 of the Constitutional Law on the Constitutional Court of Croatia.

${ }^{49}$ Constitutional Law No. 1 of 1953 and Law No. 352 of 1970.

${ }^{50}$ Articles 115 and 223 of the Constitution.

${ }^{51}$ Article 37 (1) of Law No. 47 of 1992 on the Constitutional Court of Romania.

${ }^{52}$ Article 12 of the Federal Constitutional Law of 10 October 1995 supplemented by the Constitutional Law of 27 October 2002.

53 Article 129 al. 3 of the Constitution.

${ }^{54}$ See, for example, for California, Broshanan v. EU, 31 Cal. 3d 6 (California Suprem Court); For the Mississippi: Hughes c. Hoseman, No. 2010-CA-01949-TBS, September 8, 2011, on Initiative 26 on abortion. In other states, such as Switzerland, the right of initiative enjoys constitutional protection, which precludes extensive prior control (Moeckli, 2011, 792).

${ }^{55}$ Arkansas Suprem Court, Fairness for Arkansas v. Martin, October 13, 2016 (Arkansas Cap on Medical Malpractice Attorney Fees Amendment, issue 4) ; Committee to Protect Arkansas Values '/Stop Casinos Now v. Martin, october 13, 2016 (Arkansas Three New Casinos Amendment, Issue 5) ; The Court also opposed Proposal 7 on the grounds that a number of signatures in support of the proposal were invalid: Benca v. Martin, october 27, 2016 (Arkansas Medical Cannabis Act).

${ }^{56}$ Article 139 (3) of the Constitution of the Swiss Confederation.

${ }^{57}$ Initiative « Chevalier », Feuille Fédérale, 1955 I 536.

${ }^{58}$ Feuille Fédérale 1996 I 1305.

${ }^{59}$ See on this, the website of the Swiss Federal Administration: https://www.bj.admin.ch/bj/fr/home/sicherheit/gesetzgebung/archiv/verwahrung.html

${ }^{60}$ Popular initiative "For the effective explusion of foreigners", rejected by the vote of 28 February 2016. 